\title{
Hornbill abundance in unlogged forest, selectively logged forest and a forest plantation in Arunachal Pradesh, India
}

\author{
Aparajita Datta
}

The responses of hornbills to selective logging were determined by comparing their diversity and abundance in five habitats classified according to logging history. Relative abundance of three hornbill species was compared along trails in recently logged forest, 20-25-year-old logged forest, unlogged primary forest, a relatively disturbed primary forest and a plantation in Pakhui Wildlife Sanctuary and adjoining reserve forests in western Arunachal Pradesh. The species recorded were the Oriental pied hornbill Anthracoceros albirostris, wreathed hornbill Aceros undulatus and great hornbill Buceros bicornis. The great hornbill was the most common species overall and its abundance varied across habitats, being highest in unlogged forest. The Oriental pied hornbill, which was recorded in only two habitats, seemed to show a distinct habitat preference for secondary growth, rivermargin forests. Wreathed hornbill abundance did not differ between habitats. Differences in species abundance probably reflect aspects of their ecology, such as degree of territoriality, diet and movement patterns, and differential vulnerability to hunting and disturbance. Great hornbill abundance was correlated with large tree density $(G B H \geq 150 \mathrm{~cm})$ and basal area characteristic of unlogged primary forests, while Oriental pied hornbill abundance was negatively correlated with tall forest, indicating its greater numbers in low-stature river-margin forest. Wreathed hornbill abundance was not correlated with any vegetation variable, which is probably related to its reported nomadic movements in search of fruit patches. Hornbill abundance was not correlated with densities of potential food and nest tree species. Although hornbill abundance was not correlated with fig tree density, this was probably because areas where relative fig tree densities were lower often contained a few large fruiting figs. Because hornbills are large mobile birds, they can find resources such as fruiting figs even in otherwise unsuitable habitat.

\section{Introduction}

North-east India has the highest diversity of hornbill species in the country, although there are fewer sympatric species than in south-east Asian forests. Three of the species that occur in India occur only in the north-east of the country: the wreathed hornbill Aceros undulatus, the brown hornbill Anorrhinus tickelli and the rufous-necked hornbill Aceros nipalensis. The other two species, Oriental pied hornbill
Anthracoceros albirostris and great hornbill Buceros bicornis also occur elsewhere in India. All species are listed under Schedule I of the Wildlife (Protection) Act, India, 1972. The rufous-necked hornbill is listed as Vulnerable and the brown hornbill as Near Threatened (IUCN, 1996). No comparative ecological study of these sympatric species has been carried out in India. Ecological information on these species exists from studies in South East Asia (Leighton, 1982; Leighton and Leighton, 
1983; Poonswad et al., 1983, 1986, 1987; Poonswad and Tsuji, 1994). Johns $(1983,1986$, 1987,1989 ) discussed the impacts of selective logging on hornbills in Malaysia.

During a 6-month study on the responses of arboreal mammals to selective logging in western Arunachal Pradesh, the diversity and abundance of three hornbill species were compared across five habitats to determine their response to selective logging.

\section{Study sites}

The study sites were in Pakhui Wildlife Sanctuary (WLS) and Doimara and Papum Reserve Forests (RF) in East and West Kameng districts of western Arunachal Pradesh (Figure 1). Pakhui WLS $\left(92^{\circ} 7.5^{\prime}-92^{\circ} 22^{\prime} \mathrm{E}\right.$ and $26^{\circ} 53.7^{\prime}-$ $27^{\circ} 16.2^{\prime} \mathrm{N}$ ) covers $862 \mathrm{sq} \mathrm{km}$ and is bordered to the north and west by the Bhareli River, to the east by the Pakke River and to the south by the Nameri WLS and reserve forests of Assam. Doimara RF lies to the west of Pakhui WLS in West Kameng district, while Papum RF lies to the east of the sanctuary in East Kameng district. Both these reserve forests fall in Khellong Forest Division and together cover $c .1280 \mathrm{sq} \mathrm{km}$. The sanctuary is well-drained by tributaries of the Bhareli and Pakke rivers, both of which flow into the Brahmaputra River. The terrain, in the Himalayan foothills (altitude c. 200$1500 \mathrm{~m}$ ), is undulating and hilly. The climate is subtropical, with cold weather from November to February. Both south-west and north-east monsoons occur, and the annual rainfall is c. $2500 \mathrm{~mm}$.

The general vegetation type is tropical semievergreen (Champion and Seth, 1968). The vegetation is dense with a high diversity and density of woody lianas and climbers. A total of 234 plant species (angiosperms) were recorded with a high representation of species from the Euphorbiaceae and Lauraceae (Datta and Goyal, unpubl. data). The forest has a typical layered structure and the major emergent species are Tetrameles nudiflora and Altingia excelsa (Singh, 1991). The forest types include: tropical semi-evergreen on the lower plains and foothills, dominated by Terminalia myrio- carpa, Ailanthus grandis and Duabanga grandiflora (Singh, 1991); patches of tropical evergreen forests, dominated by Altingia excelsa, Mesua ferrea, Dysoxylum spp., and mid-storey trees (Lauraceae and Myrtaceae); and subtropical broadleaved forests on the hilltops and higher reaches, dominated by members of the Fagaceae and Lauraceae. Moist areas near streams have a profuse growth of bamboo, cane brakes and palms. Patches of tall grassland and shingle beds occur along the larger perennial streams, which give way to lowland moist forests containing Dillenia indica and Talauma hodgsonii.

During this study, c. 150 bird species were recorded. Several other bird species were recorded by Singh (1991, 1995). Three primate species and four squirrel species are the most commonly encountered arboreal mammals. Several species of civet and the yellowthroated marten Martes flavigula, a putative predator of hornbills, also occur. Other carnivore fauna include tiger Panthera tigris, leopard Panthera pardus, clouded leopard Neofelis nebulosa and smaller cats.

\section{Details of survey areas}

Five habitats were selected based on logging history. The habitats were: recently logged forest and a mixed species plantation in Doimara and Papum RF, respectively; and 20-25-yearold logged forest; semi-disturbed forest; and unlogged primary forest, in Pakhui WLS. The location of the trails are marked on Figure 1.

\section{Plantation - Trail 1, Seijusa-Monai (Papum RF)}

A logging road $(3.45 \mathrm{~km})$ was walked 10 times in the mixed plantation (altitude $400-500 \mathrm{~m}$ ). The plantation contained small single-species patches among a mixture of hardwood species. The major species were Terminalia myriocarpa, Duabanga grandiflora, Phoebe goalparensis, Bombax ceiba, Gmelina arborea and the introduced Tectona grandis. Small patches have been planted with species at various times since 1959. A few large Ficus trees are virtually all that remains of the natural vegetation. 


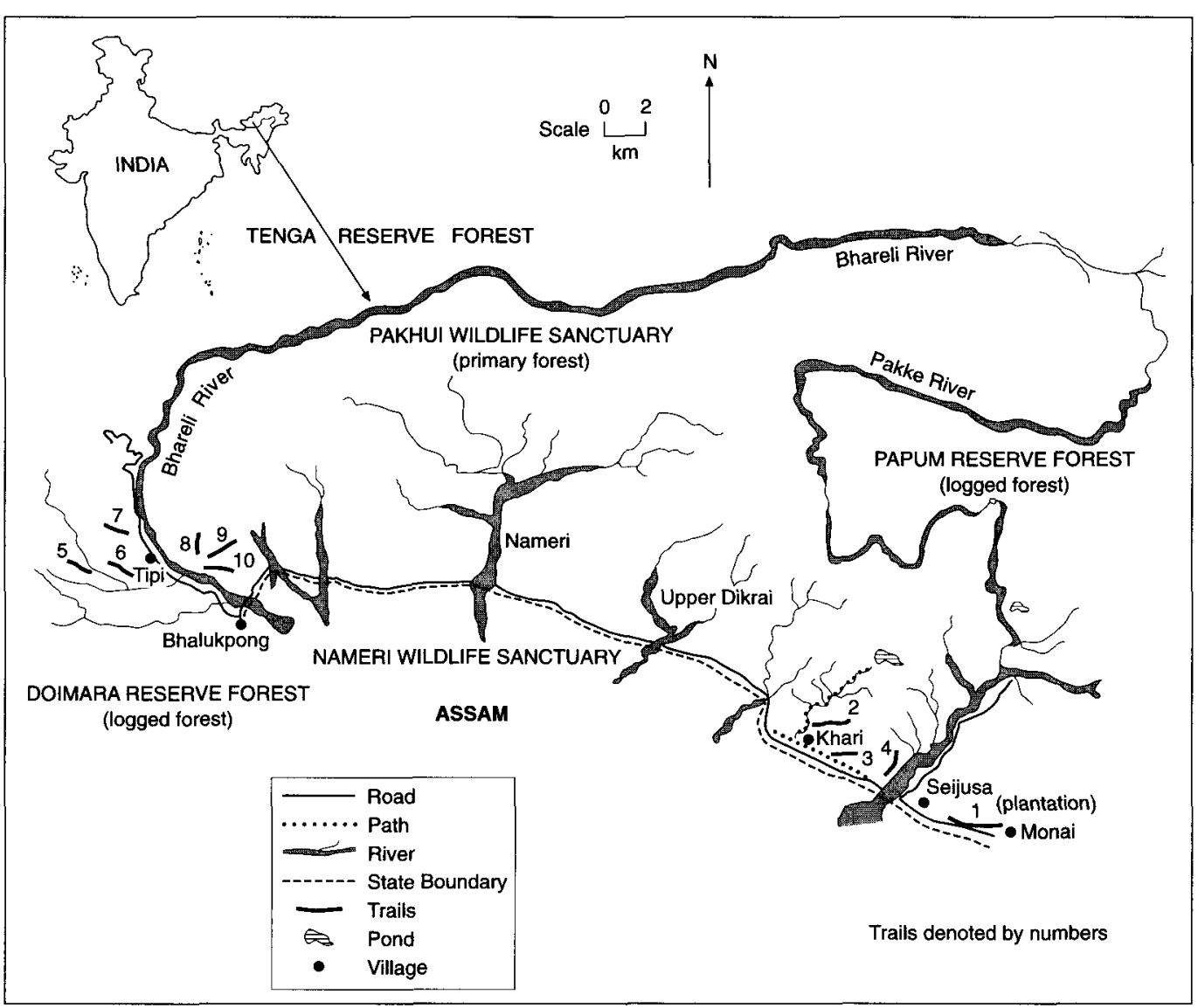

Figure 1. Map of Pakhui WLS and adjacent reserve forests, East and West Kameng district, western Arunachal Pradesh.

Little extraction has occurred from the plantation. The plantation borders the reserve forests of Assam and there are settlements and villages surrounding it along with patches of cultivation and degraded forest. The total area covered by these plantations is $c .3-4 \mathrm{sq} \mathrm{km}$.

\section{Semi-disturbed forests - Trails 2 and 3, Khari} (Pakhui WLS)

A total of $31 \mathrm{~km}$ was walked in semi-disturbed forest (altitude $450-550 \mathrm{~m}$ ) following two trails seven times each. These were basically elephant trails/paths and were cut further for the census walks. The trails were adjacent to steep gullies and nalas; canes and palms were abundant, and bamboo clumps occurred on the slopes. Hillsides were dominated by Mesua ferrea and Castanopsis spp. Dillenia indica was common on the river banks. Abandoned clearings with thick weedy undergrowth indicated that human settlements existed here in the past. Cane extraction on a commercial basis occurred until 1991 and occasionally cane-cutters enter these forests from the adjacent reserve forests of Assam. The area is adjacent to Nameri WLS of Assam and has not undergone selective felling in the past.

\section{Old logged forest - Trail 4, Seijusa-Khari (Pakhui} WLS)

A single $2.7-\mathrm{km}$ patrol trail cut by the Forest Department staff in 1994 was walked 10 times 
in old logged forest (altitude 550-800 m). An area of $c .4 \mathrm{sq} \mathrm{km}$ had undergone some selective felling in the past (c. 20-25 years ago) before Pakhui was declared a sanctuary in 1978. The presence of very old cut stumps and reports from elderly tribal people and Forest Department staff confirmed that felling had occurred here. This area lies near the Arunachal Pradesh-Assam border and contains several colonizing species, such as Bauhinia purpurea and Mallotus sp., which are common in secondary forests.

\section{Logged forest - Trails 5, 6 and 7, Tipi, west of Bhareli River (Doimara RF)}

Three logging roads varying in length from 1.7 to $3 \mathrm{~km}$ were used for the census walks in logged forest (altitude $500-850 \mathrm{~m}$ ) and were followed eight times each - a total distance of $53 \mathrm{~km}$. The area is close to Tipi town with a population of about 900 . There are two sawmills and one plywood/veneer mill here. Logging operations were being carried out along two of the trails and had been completed 5-6 months previously on the third trail. There were one or two small labour camps in the logged forest sites. Elephants and small trucks were used to transport the logs from side roads and the main logging road to the mills. North-west of this area there are still unlogged areas of reserve forest in inaccessible terrain. To the north of this reserve forest lies Eagle's Nest WLS, and to the west and south, Amartala RF and reserve forests and villages of Assam, respectively. The Bhareli River and the Tezpur-Bomdilla highway act as the boundary between Pakhui WLS and Doimara RF.

\section{Unlogged primary forest - Trails 8, 9 and 10, Tipi, east of Bhareli River (Pakhui WLS)}

Census walks totalled $41.4 \mathrm{~km}$ in unlogged primary forest. The three trails - two patrol trails maintained by the Forest Department and a third trail cut especially for the census walks were near the south-western boundary of the sanctuary across the Bhareli River from Tipi. $A$ vast portion in the central and northern part of the sanctuary is quite inaccessible as a result of the dense vegetation, hilly terrain and the lack of trails. Consequently, very few people, even local tribal people, venture into the interior of the forest. The sole village, Mabusa, to the south of the sanctuary has been relocated outside. There are one or two settlements near the northern boundary. The Bhareli River acts as a barrier to the pressures of human disturbance, although occasionally local tribal people cross over. Therefore, most of Pakhui WLS, except a small strip to the south, has undisturbed primary forest.

\section{Methods}

Ten trails were walked in the five habitats, 610 times each, during the study period from December 1995 to April 1996. All trails were monitored in the morning. The total distance walked was $187.12 \mathrm{~km}$. Relative hornbill abundance was compared using a simple measure of encounter rate: numbers seen per $\mathrm{km}$. Calls were used only for confirmation of species presence. Flock sizes were also recorded. Data on vegetation structure and composition were collected in 198 circular plots of $10 \mathrm{~m}$ radius (0.031 ha) along the trails. All trees $\geq 25 \mathrm{~cm}$ $\mathrm{GBH}$ were enumerated. The species, GBH, tree height, crown width of all trees and the presence of lianas were recorded in each plot.

Because fig fruits are an important component of hornbill diet (Lambert, 1991; Kannan, 1994), individual fig trees were counted along the census trails and perpendicular distances estimated. Fig densities were calculated within a strip width after correcting for differential visibility. Hornbill abundance was correlated with various structural characteristics of the forests as well as fig-tree densities in each habitat. The density of certain known nest-tree species (Poonswad et al., 1983; Poonswad, 1995, and local information) was calculated and correlated with hornbill abundance. All individuals of these known nest species with $\mathrm{GBH} \geq 125 \mathrm{~cm}$ (the minimum size used by hornbills, according to Poonswad, 1995) were tallied, and their density in each habitat calculated. The density of several 
potential food trees (from Poonswad et al., 1983, 1986, 1987, and local information) in each habitat was also calculated to determine whether hornbill abundance was correlated with density of food species other than figs.

Non-parametric tests, such as KruskalWallis one-way ANOVA and Mann-Whitney $U$ tests were used to test for differences in abundance across habitats and pairs of habitats, while Spearman's rank correlation was used to correlate habitat variables with hornbill abundance. Data were analysed using the SPSS/PC software package (Norusis, 1990).

\section{Results}

Three hornbill species were recorded, Oriental pied hornbill, wreathed hornbill and the great hornbill. The total number seen was 165 , the great hornbill being the most abundant $(0.44 \pm$ $0.12 / \mathrm{km})$, followed by wreathed hornbill $(0.32$ $\pm 0.07 / \mathrm{km})$ and Oriental pied hornbill $(0.10 \pm$ $0.05 / \mathrm{km})$. Species could not be identified in four sightings.

Great and wreathed hornbill were recorded in all habitats, while Oriental pied hornbill was recorded only in semi-disturbed forest and plantation (Table 1). A flock of this species was seen in unlogged forest once but was not recorded on a transect. Abundance of great hornbill and Oriental pied hornbill differed significantly across habitats $\left(\chi^{2}=9.53\right.$ for great hornbill, $P<0.05, \chi^{2}=13.5$ for Oriental pied hornbill, $P<0.01)$. Wreathed hornbill abundance did not vary significantly across habitats.

Pairwise comparison between habitats showed that great hornbill abundance was significantly higher in unlogged forest than in logged forests, semi-disturbed forests and old logged forests (Mann-Whitney $U$-tests, $P<$ 0.05 ). The mean flock size of the great hornbill and the wreathed hornbill was 2.1, while that of the Oriental pied hornbill was 3.3. Fifty per cent of the sightings $(n=18)$ of the great hornbill were of a single bird, while 39 per cent ( $n$ $=14$ ) were of pairs. Flocks of great hornbill were seen twice on fruiting trees in unlogged primary forest. Thirty-three per cent of the sightings $(n=10)$ of wreathed hornbill were of a single bird, while 43 per cent $(n=13)$ were of pairs. Seven sightings were of birds in flocks of 3-5 individuals. Of the seven sightings of the Oriental pied hornbill, one was of a flock of nine birds in the plantation, the rest of the birds were seen in flocks of 1-5.

Large tree density ( $\mathrm{GBH} \geq 150 \mathrm{~cm}$ ), canopy cover and basal area were highest in unlogged primary forest (Table 2). The major difference in logged forest was the reduction in tree density and basal area. Although overall tree density and canopy cover were high in semi-disturbed forest (Table 2), basal area was much lower as a result of the large number of small trees ( 78 per cent were $<75 \mathrm{~cm} \mathrm{GBH}$ ). Fig densities were highest in unlogged forest and lowest in old logged forest and plantation (Table 3).

Great hornbill abundance was positively correlated with large tree density (both $\mathrm{GBH} \geq$ $150 \mathrm{~cm}$ and $\geq 200 \mathrm{~cm}, \mathrm{r}_{\mathrm{s}}=0.74, \mathrm{r}_{\mathrm{s}}=0.60, P<$ $0.05)$ and basal area $\left(r_{s}=0.60, \quad P<0.05\right)$. Wreathed hornbill abundance, on the other hand, was not correlated with any vegetation variable. Oriental pied hornbill abundance was negatively correlated with mean tree height $\left(\mathrm{r}_{\mathrm{s}}=-0.674, P<0.05\right)$.

Table 1. Hornbill abundance (no/ $/ \mathrm{km}$ ) in five habitats

\begin{tabular}{lllll}
\hline Habitat & $\begin{array}{l}\text { Distance } \\
\text { walked }(\mathrm{km})\end{array}$ & $\begin{array}{l}\text { Great } \\
\text { hornbill }\end{array}$ & $\begin{array}{l}\text { Wreathed } \\
\text { hornbill }\end{array}$ & $\begin{array}{l}\text { Oriental } \\
\text { pied hornbill }\end{array}$ \\
\hline Unlogged forest & 41.4 & $1.16 \pm 0.41$ & $0.32 \pm 0.13$ & 0.00 \\
Semi-disturbed forest & 30.94 & $0.17 \pm 0.12$ & $0.23 \pm 0.11$ & $0.39 \pm 0.19$ \\
Old logged forest & 27.0 & $0.15 \pm 0.08$ & $0.44 \pm 0.34$ & 0.00 \\
Logged forest & 53.28 & $0.10 \pm 0.04$ & $0.35 \pm 0.14$ & 0.00 \\
Plantation & 34.5 & $0.41 \pm 0.23$ & $0.29 \pm 0.14$ & $0.24 \pm 0.24$
\end{tabular}


Hornbill abundance was not correlated with the densities of potential nest-trees, fig trees or other potential food species (largely Lauraceae and Meliaceae, with a few Anacardiaceae, Burseraceae, Euphorbiaceae, Fagaceae, Myristicaceae and Myrtaceae). It was also not correlated with densities of particular food species, such as Dysoxylum binectariferum and Chisocheton paniculates (both hornbill food species important in the diet here).

\section{Discussion}

From the limited data set it is probably not appropriate to generalize patterns in the abundance of species. However, a clear result is the overall higher abundance of hornbills, especially of the great hornbill, in unlogged forest. The larger numbers of the great hornbill seen in unlogged forest is possibly due to the high density and biomass of trees. Its lower numbers in semi-disturbed forest is possibly due to lack of suitable habitat as evidenced by lower biomass and small trees. Although canopy cover and tree density were high, the density of large trees was very low.

Hornbill abundance was not correlated with canopy cover. Their abundance was surprisingly high in the plantation, which had low canopy cover. However, all instances of hornbill sightings in the plantation were of individuals or flocks on fruiting fig trees or flying to fig trees. Therefore, their presence is probably a result of the local availability of fruiting figs during the study period. Of a total of 29 hornbills seen in the plantation, 13 were great hornbill, 7 were wreathed hornbill and 9 were Oriental pied hornbill.

Fig densities were higher in the logged forest than in the plantation, but greater human disturbance may have resulted in the lower abundance of hornbills in logged forest.

Of all the hornbill species, the wreathed hornbill is the most frugivorous, especially of lipid-rich drupaceous fruits, even in the breeding season when other species take more animal material (Leighton and Leighton, 1983; Poonswad et al., 1983, Poonswad and Tsuji, 1994). Consequently, the wreathed hornbill 
Table 3. Fig, food-species and nest-species densities in five habitats

\begin{tabular}{lllll}
\hline Habitat & $\begin{array}{l}\text { Fig density } \\
\text { per ha }\end{array}$ & $\begin{array}{l}\text { Food-tree } \\
\text { density per ha }\end{array}$ & $\begin{array}{l}\text { Food-tree } \\
\text { density per ha } \\
(\mathrm{GBH} \geq 50 \mathrm{~cm})\end{array}$ & $\begin{array}{l}\text { Nest-tree species } \\
\text { density per ha }\end{array}$ \\
\hline Unlogged forest & 1.48 & 161.93 & 92.04 & 21.59 \\
Semi-disturbed forest & 0.56 & 206.81 & 106.6 & 3.18 \\
Old logged forest & 0.55 & 189.67 & 115.0 & 9.79 \\
Logged forest & 1.25 & 74.72 & 48.69 & 10.12 \\
Plantation & 0.29 & 50.91 & 38.0 & 0.0 \\
\hline
\end{tabular}

Potential nest tree species include Tetrameles nudiflora, Altingia excelsa, Ailanthus grandis, Lagerstroemia sp., Sterculia sp., Ficus spp. and Cinamommum sp.

has to travel further to forage than the other species. The species is wide-ranging and seminomadic, moving over relatively large areas . It travels more than $10 \mathrm{~km}$ between feeding sites and roosts outside the breeding season (Leighton, 1986). The great and Oriental pied hornbills, on the other hand, are territorial throughout the year (Kemp, 1979; Kannan, 1994). Wreathed hornbill abundance was not correlated with any habitat variable, possibly because of its wide-ranging movements and presence in all kinds of habitats. This is a rare instance of a specialist (in terms of diet) being more of a habitat generalist because of its dependence on a resource that is patchy in time and space.

The Oriental pied hornbill was recorded only in semi-disturbed forest, and once in the plantation. This species seems to be present in areas that were at slightly lower elevations, and in lower-stature, river-margin forests. It was particularly common along two larger perennial streams (near semi-disturbed forest). Its greater abundance in secondary growth forest and lowland, river-margin forest suggested that it has a distinctly different habitat preference compared with other species. The abundance of this species was negatively correlated with tree height. Payne (1980) and Johns (1987) also recorded it only in river margin forest or secondary forests along rivers. Wells (1985) also reported it as being an extreme lowland specialist. It is reported to feed on fruits of fast growing lianas in riparian forest (Johns, 1987). Oriental pied hornbills are also more omnivorous, feeding more on animal matter (Poonswad et al., 1983). Species differences in the use of habitats have been reported in other studies (Payne, 1980; Johns, 1987).

Hornbills are known to exploit three main kinds of fruit-lipid-rich capsular fruits (Meliaceae, Myristicaceae), lipid-rich drupaceous fruits (Lauraceae, Annonaceae) and sugar-rich figs (Ficus spp.). During this study, hornbills were seen on fruiting trees of Dysoxylum binectariferum, Chisocheton paniculates and Ficus spp., as well as some lianas. Fig densities are reportedly an important determinant of hornbill abundance (Rijksen, 1978), although no correlations were established in the present study. Although fig densities were relatively lower in the plantation, the presence of even a few large fruiting individuals caused an influx of hornbills into an otherwise unsuitable habitat. In the plantation, five to six large fig trees fruited sporadically during the 5month study period. Even areas with lowered densities of figs will have hornbills, as long as some fruiting figs remain and the areas are not separated by great distances from large patches of primary forest. These birds probably track food resources such as ephemeral fruiting figs, in which there is intra-tree synchrony in ripe fruit abundance and hence their movements are dictated by the local availability of fruiting trees at a given period of time. Suryadi et al. (1996) also predicted that hornbill ranging is influenced by fig-fruit availability, although their phenological data did not support this. They concluded that the scale of their fig study was probably inappropriate for 
the large-scale movements of hornbills. In this study too, the lack of correlation may be due to the scale of the study or to small sample sizes. In addition, other factors, such as the relative abundance and diversity of food sources such as lianas and animal matter were not quantified.

Hornbills select nests on the basis of availability and other criteria. Therefore, as long as some cavity-bearing trees of particular species are present, broad-scale correlational analysis of hornbill abundance with potential nest-tree densities may not show fine-scale patterns in species abundance and distribution.

\section{Conservation of hornbills}

Although Johns (1987) found the greatest diversity and abundance of hornbill species in undisturbed forest, most are able to survive in selectively logged forest, despite the high proportion of food species lost during timber extraction (Kemp and Kemp, 1975; Johns, 1986). Hornbills are adapted to exploit food resources that are rare and widely dispersed, and hence most species range over large areas of forest (Johns, 1983). Logged forests cover larger areas than primary forest, and therefore should be included in conservation strategies (Johns, 1987).

Large areas of primary forest still exist in Arunachal Pradesh, mainly as a result of low population densities and inaccessible terrain. Although c. 62 per cent of the geographical area is under forest cover, habitat loss/conversion due to logging, shifting agriculture and development activities are accelerating (Katti et al., 1992). Logged forests or other classes of forest occupy much larger areas than totally protected areas in Arunachal Pradesh. The State has nine wildlife sanctuaries and two national parks covering $9246 \mathrm{sq} \mathrm{km}$. Of the total forest area (c. $51,540 \mathrm{sq} \mathrm{km}), 9815 \mathrm{sq} \mathrm{km}$ is classified as reserve forest. The rest are protected forests, village reserve forests and unclassified state forests, which are subject to various kinds of disturbance. Unclassified state forests, where tribal people have several rights, comprise the largest forest area, approximately $35,802 \mathrm{sq} \mathrm{km}$ (about 70 per cent of the forest area). Only 18 per cent of the forest area, or 11 per cent of the total geographical area is under the protected area network. Plantations are unlikely to be used by hornbills for breeding because of the absence of large cavity-bearing trees, but they are definitely used as feeding areas as recorded in this study. Therefore, although hornbills are unlikely to persist solely in areas of early secondary growth and monoculture plantations, it is necessary to include forests outside the protected area network (national parks and sanctuaries) in conservation plans. Wildlife populations in managed forests are usually not given adequate importance in overall conservation plans (Johns, 1985).

During the present study, hornbills were seen frequently to travel between primary forest areas and logged forest and plantations. Only the Bhareli River and a highway separate the primary unlogged forest (Pakhui WLS) and the logged forest (Doimara RF). Hornbills were seen frequently flying back and forth between the two areas especially in the early morning hours and at dusk.

\section{The importance of fig trees}

Large mature fig trees are not usually felled during operations in the study area (pers. obs.), although in one instance a fig tree, which had encircled a large Terminalia myriocarpa, had been felled because of the commercial value and rarity of this timber species in the wild. Strangler fig trees are purported to prefer large-girth tall trees (many of which are timber species) as hosts (Leighton and Leighton, 1983; Lambert, 1991; Patel, 1996). Their availability can be reduced in logged forest and this, coupled with the cutting of lianas and epiphytic strangling figs during and after the felling operation would affect their recruitment into the population (Leighton and Leighton, 1983; Datta, unpubl. data). About 50 per cent of strangler figs used timber species as hosts in the study area (Datta, unpubl. data). The percentage of juvenile figs was also lower in logged forest compared with that in unlogged forest (Datta, unpubl. data). Disproportionate loss of fig 
trees may adversely affect large hornbills (Leighton and Leighton, 1983). Hornbills are important dispersal agents for figs and many primary forest species (some of which are commercially valuable timber species), and therefore may be very important in maintaining the diversity and abundance of tree species in managed forests. Therefore it is in the interest of the forest managers and loggers to take certain measures to conserve hornbills.

\section{Hunting and other factors}

A more serious proximate threat to hornbills, especially in logged forests, is hunting by tribal people. Historically, this group of birds has been subjected to hunting all over its range. The feathers, casque and beak, especially of the great hornbill, are used by several tribal groups for ceremonial costumes and even daily traditional headgear. Hornbill meat is valued for its flesh and the medicinal value of its fat. Certain taboos exist among some tribal groups, which prevent hunting during the breeding season. High levels of hunting of hornbills seem to exist in eastern AP especially among the Wanchos of Tirap district. This has led to the extreme rarity of the great hornbill in reserve forest areas there.

Katti et al. (1992) reported that hunting by tribal people is more severe in the foothill forests near villages and this, coupled with an increase in non-tribal populations and accompanying road construction, results in more disturbance. Hornbills and pheasants are worst affected by hunting (Katti et al., 1992). Therefore, even though logging may not be directly affecting these birds, the construction of roads in logged areas leads to increased accessibility for hunting. Nevertheless, hornbills in logged forests move to and from unlogged forest, which act as refuges, and are relatively safe from hunting because of the sanctuary (unlogged forest) across the Bhareli River.

Although similar hunting pressures are likely in the logged forest and plantation, all three known instances of hunting (all of great hornbill) occurred in Doimara RF during the course of this work. The presence of loggers' camps, movement of elephants and trucks, labour involved in road-repairs, and planting of saplings once the logging operations were over, resulted in greater immediate human disturbance than in the plantation, where no operations were being carried out. People were also often encountered in the logged forests on the trails with sling shots, catapults and shotguns. This, coupled with lower tree cover and loss of large trees, may be the reason for the low hornbill abundance in logged forest. The great hornbill is the state bird of Arunachal Pradesh, and this species and the rufous-necked hornbill are greatly valued by most tribal groups, but an awareness campaign is necessary to draw attention to the fact that increased hunting coupled with habitat loss can seriously affect the species. In recent years, in addition to traditional hunting with bow-and-arrow or shotguns, the younger generation (local people and outsiders) travel in vehicles and shoot hornbills at roosting or large fruiting fig trees. There is a self-imposed ban on hunting hornbills during the breeding season (MarchAugust) by the major tribal community (Nishis) in this part of East Kameng district (Seijusa area), which is encouraging for the future conservation of hornbills in this area. This kind of taboo should be also encouraged in other areas of Arunachal Pradesh.

\section{Acknowledgements}

This work was carried out during field work for a project funded by the Wildlife Institute of India and I thank the Director, WII, for the facilities provided there. I thank the Arunachal Pradesh Forest Department for permission to work in the field, especially D. N. Singh (DFO, Pakhui WLS), Oni Dai (DFO, Khellong Forest Division) and Pratap Singh (DCF, Itanagar) for their help and support during field work. Helpful comments on the manuscript were given by Charudutt Mishra and later by T. R. Shankar Raman and an anonymous reviewer. Dinesh Pundeer is thanked for preparing the map.

\section{References}

Champion, H.G. and Seth, S.K. 1968. A Revised Survey of the Forest Types of India. Manager of Publications, Government of India, New Delhi. 
IUCN. 1996. 1996 Red List of Threatened Animals. IUCN, Gland, Switzerland.

Johns A.D. 1983. Wildlife can live with logging. New Scientist, 99, 206-211.

Johns, A.D. 1985. Selective logging and wildlife conservation in tropical rainforest: problems and recommendations. Biological Conservation, 31, 355-375.

Johns, A.D. 1986. Effects of selective logging on the ecological organization of a peninsular Malaysian rainforest avifauna. Forktail, 1, 65-79.

Johns, A.D. 1987. The use of primary and selectively logged rainforest by Malaysian hornbills (Bucerotidae) and implications for their conservation. Biological Conservation, 40, 179-190.

Johns, A.D. 1989. Recovery of a Peninsular Malayasian rainforest avifauna following selective timber logging: the first twelve years. Forktail, 4, 89-106.

Kannan, R. 1994. Ecology and conservation of the great pied hornbill (Buceros bicornis) in the Western Ghats of southern India. PhD thesis, University of Arkansas.

Katti, M., Singh, P., Manjrekar, N., Mukherjee, S. and Sharma, D. 1992. An ornithological survey in eastern Arunachal Pradesh, India. Forktail, 7, 75-89.

Kemp, A.C. 1979. A review of hornbills: biology and radiation. The Living Bird, 17, 105-136.

Kemp, A.C. and Kemp, M.I. 1975. Report on a study of hornbills in Sarawak, with comments on their conservation. WWF, Kuala Lumpur, Malaysia.

Lambert, F. 1991. The conservation of fig-eating birds in Malaysia. Biological Conservation, 58 (1), $31-40$.

Leighton, M. 1982. Fruit resources and patterns of feeding, spacing and grouping among sympatric Bornean hornbills (Bucerotidae). PhD thesis, University of California (Davis).

Leighton, M. 1986. Hornbill social dispersion: variations on a monogamous theme. In Ecological Aspects of Social Evolution (eds D. Rubenstein and R.W. Wrangham), pp. 108-130. Princeton University Press, Princeton, New Jersey.

Leighton M. and Leighton, D.R. 1983. Vertebrate responses to fruiting seasonality within a Bornean rain forest. In Tropical Rain Forest: Ecology and Management (eds S. L. Sutton, T. C. Whitmore and A. C. Chadwick), pp. 181-196. Blackwell Scientific Publications, Oxford.

Norusis, M.J. 1990. SPSS/PC+4.0 Base ManualStatistical Data Analysis. SPSS Inc.

Patel, A. 1996. Strangler fig-host associations in roadside and deciduous forest sites. Journal of Biogeography, 23 (4), 409-414.

Payne, J.B. 1980. Competitors. In Malayan Forest Primates (ed. D. J. Chivers), pp. 261-277. Plenum
Press, New York and London.

Poonswad, P. 1995. Nest site characteristics of four sympatric species of hornbills in Khao Yai National Park, Thailand. Ibis, 137, 183-191.

Poonswad, P. and Tsuji, A. 1994. Ranges of males of the Great Hornbill Buceros bicornis, Brown Hornbill Ptilolaemus tickelii and Wreathed Hornbill Rhyticeros undulatus in Khao Yai National Park, Thailand. Ibis, 136, 79-86.

Poonswad. P., Tsuji, A. and Ngampongsai, C. 1983. A study of the breeding biology of hornbills (Bucerotidae) in Thailand. Proceedings of the Jean Delacour/ICFB Symposium on Breeding Birds in Captivity. February 24-27, 1983, Los Angeles, California, USA.

Poonswad. P., Tsuji, A. and Ngampongsai, C. 1986. A comparative ecological study of four sympatric hornbills (Family Bucerotidae) in Thailand. Acta XIX Congressus Internationalis Ornithologici. Vol.II, June 22-29, 1986, Ottawa, Canada. University of Ottawa Press.

Poonswad. P., Tsuji, A. and Ngampongsai, C. 1987. A comparative study on breeding biology of four sympatric hornbill species (Family Bucerotidae) in Thailand with implications for breeding in captivity. Proceedings of the Jean Delacour/ICFB Symposium on Breeding Birds in Captivity. February 11-15, 1987, Los Angeles, California, USA.

Rijksen, H.D. 1978. A Field Study of the Sumatran Orang-utan (Pongo pygmaeus abelii, Lesson, 1827): Ecology, Behaviour and Conservation. H. Veenman and Zonen, Wageningen, Holland.

Singh, P. 1991. Avian and mammalian evidences in Pakhui Wildlife Sanctuary in East Kameng district, Arunachal Pradesh. Arunachal Forest News, 9 (2), 1-10.

Singh, P. 1995. Recent bird records from Arunachal Pradesh. Forktail, 10, 65-104.

Suryadi, S., Kinnaird, M.F. and O'Brien, T.G. 1996. Home range and daily length of the Sulawesi redknobbed hornbills Aceros cassidix during the nonbreeding season. Abstract, The Second International Asian Hornbill Workshop, 10-18 April 1996.

Wells, D.R. 1985. The Forest avifauna of Western Malesia and its conservation. In Conservation of Tropical Forest Birds (eds A. W. Diamond and T. E. Lovejoy), pp. 213-232. International Council for Bird Preservation, Cambridge.

Wildlife (Protection) Act, (India). 1972. Natraj Publishers, Dehradun.

Aparajita Datta, Wildlife Institute of India, Post Bag \# 18, Dehradun 248-001, India.

Received 26 March 1997

Accepted 31 March 1998 